\title{
Linking Geoheritage and Traditional Architecture for Mitigating Depopulation in Rural Areas: the Palaeozoic Villages Route (Courel Mountains UNESCO Global Geopark, Spain)
}

\author{
Daniel Ballesteros ${ }^{1,2,3} \cdot$ Pablo Caldevilla ${ }^{1,4}\left([) \cdot\right.$ Ramón Vila $^{1,5} \cdot$ Xose Carlos Barros ${ }^{1} \cdot$ Martín Alemparte $^{1,6}$
}

Received: 26 October 2020 / Accepted: 6 May 2021 / Published online: 4 July 2021

(c) The Author(s) 2021, corrected publication 2021

\begin{abstract}
The use of stone in traditional architecture represents one of the most relevant links between geological and cultural heritage. As a topic of general interest and easily understandable to all public, this link is a guiding thread for touristic routes mitigating the depopulation trend that affects large inland rural areas, including many areas in UNESCO Global Geoparks (UGGp). In the northwest of Spain, the Courel Mountains UGGp created the Palaeozoic Villages Route for touristic purposes in 2018, highlighting the relevance of local stones in traditional architecture as a key feature for sustainable development. For the design and creation of this route, seven villages were selected along six criteria: (1) the representativeness of the building stone with the bedrock of the UGGp, (2) the preserved traditional architecture, (3) their link with geoheritage, (4) the scenic beauty of their surroundings, (5) the potential combination with other touristic activities, and (6) the presence of local services. The Palaeozoic Villages Route exhibits four rock types/sections/structures spanning four Palaeozoic periods, as well as different uses for walling and roofing depending on the rock feature. Since 2018, the route experienced an increased revenue of $19 \%$ in the touristic sector to the traditional villages, while visitors used up to $61 \%$ of the local services of the UGGp for one or more days. In addition, the route reinforces the awareness of depopulation and abandonment of rural villages, fostering the purchase and/or restoration of dwellings as second regular residences in tranquil and scenic environments. In the short to medium term, these actions are expected to reverse or, at least, minimise the loss of population in the UGGp.
\end{abstract}

Keywords Depopulation · Geotourism · Courel Mountains UGGp · Rural areas · Traditional architecture

\section{Introduction}

In the twenty-first century, depopulation continues to strongly affect large rural areas, being one of the main socioeconomic issues of many UNESCO Global Geoparks (UGGp), due to the lack of industry and service sectors (Takenouchi et al. 2018; Van Geert 2019; Telbisz et al.
2020). At the same time, these deficits favoured the preservation of villages with a traditional architecture, laying the bases for sustainable rural tourism (Lane and Kastenholz 2015; Gao and Wu 2017). As traditional architecture is frequently preserved in stone, it provides a great opportunity to link cultural and geological heritages as a touristic resource for all public (Gordon 2018; La Felice et al. 2019). To this
Daniel Ballesteros

ballesteros@geol.uniovi.es

Pablo Caldevilla

pcald@unileon.es

Ramón Vila

concello.quiroga@eidolocal.es

Martín Alemparte

grupogdr8@yahoo.es

1 Courel Mountains UNESCO Global Geopark, Rúa do Courel 21, 27320 Quiroga, Spain
2 Department of Geodynamics, University of Granada, Campus de Fuentenueva s/n, 18071 Granada, Spain

3 UMR 6266 IDEES, University of Rouen-Normandy/CNRS, Mont Saint-Aignan CEDEX, France

4 High Technical School of Mine Engineering, University of León, Campus de Vegazana, s/n, 24071 León, Spain

5 Geological Museum of Quiroga, Rúa do Courel 21, 27320 Quiroga, Spain

6 Ribeira Sacra-Courel Local Action Group, Rúa Doctor López Lallana $6-1^{\circ} \mathrm{D}, 27340$ Bóveda, Spain 
end, many remarkable historical monuments preserved in stone were declared UNESCO World Heritage sites (Larsen and Wijesuriya 2015). The Art of Dry-Stone Walling (loadbearing walls of interlocking stones, without mortar) of Croatia, Cyprus, France, Greece, Italy, Slovenia, Spain, and Switzerland (2018) is an example of the harmonious relationship between traditional architecture and geology, with a particular touristic appeal in rural areas (Mallafrè Balsells et al. 2019). Other examples linking cultural heritage and rock geology are Global Heritage Stone Resource (GHSR) and Global Heritage Stone Province (GHSP), designations related to stone largely used for historical buildings at regional or international scale for a significant historical period (Pereira and Marker 2016).

The economic sustained development of UGGp's is based on the integration of its geoheritage and local relations with cultural heritage and biodiversity (e.g. Brilha 2018; Sá and Rocha 2020). The depopulation trend has been one of the larger challenges for geoparks since their beginnings (Nowlan et al. 2004), centring activities and efforts to avoid the negative socioeconomic impacts of local population declines (Ramsay 2017; Alcalá 2018; Álvarez 2020), often by linking geological and cultural heritages (Scarlett and Riede 2019; Carvalho et al. 2020). In Spain, territorial policies against the depopulation of rural areas are mainly based on cultural tourism (Sánchez-Mesa 2019). The growing Spanish Geoparks Forum is currently implementing geoheritage in fifteen areas for reversing the demographical situation (Hilario and Carcavilla, 2020), including the Palaeozoic Villages Route (PVR) in the Courel Mountains UGGp created in 2018. This route highlights the role played by representative local stones on the traditional architecture of rural villages as a key point for sustainable development. The relationship between geoheritage and the local town communities constitutes the cornerstone of the UGGp as the main differentiating thematic feature. Here, we discuss the design of the PVR combining cultural, geological, and other criteria, as well as the analyses of its benefits and potential disadvantages for the area and its local populations.

\section{Setting}

The Courel Mountains UGGp $\left(42.48^{\circ} \mathrm{N}, 7.28^{\circ} \mathrm{W}\right)$ is located in Galicia, the most northwest Spanish region of the Iberian Peninsula (Fig. 1A). The UGGp covers an area of 578 $\mathrm{km}^{2}$, comprising three municipalities (Folgoso do Courel, Quiroga, and Ribas de Sil) and 190 villages (Fig. 1B), most of them with less than ten residents. The municipalities manage the UGGp under the direction of the Ribeira Sacra-Courel Local Action Group. The UGGp contains tourism offices, museums, viewpoints, and other tourism sites, as well as over 60 geosites (Fig. 1C). According to the
National Statistics Institute (INE) of Spain, the population has declined by $30 \%$ in the UGGp since 2000 , reporting 5178 inhabitants in 2019 (9.0 inhabitants per $\mathrm{km}^{2}$ ), urging the development of new adaptive strategies for inland touristic destinations based on cultural and natural aspects (De Uña-Álvarez and Villarino-Pérez 2017).

As a mountainous territory, the weather during the touristic period is constrained by the Atlantic climate $\left(3-29^{\circ} \mathrm{C}\right)$ with temperate summers and an annual precipitation of $1100 \mathrm{~mm}$. Peak precipitation falls in winter during which a snow cover appears (Csb climatic type according to Cunha et al. 2011). Tens of thousands of tourists visit the UGGp annually for cultural and outdoor activities, especially in summer, but also in autumn for watching the intense colours of the preserved native deciduous woodlands (Fig. 1B). These forests, formed by oaks, birchs, hazels, and beeches, and their associated fauna motivated the declaration of a Community Site of Interest (European Nature 2000 Network) in the northern mountains, where traditional woodlots produce chestnuts as a local product (Guitián et al. 2012). In the south of the UGGp, an orographic rain shadow favours the development of Mediterranean conditions allowing the elaboration of local wine and olive oil, both with an indication of the official Designation of Origin (Fig. 1C).

The geoheritage of the Courel Mountains UGGp is highlighted by its tectonic, stratigraphic, geomorphological, and mineral resources and claims attention at national or international scales. The UGGp lies in the metamorphic areas of the Variscan Domain and its bedrock, Neoproterozoic to Carboniferous in age (Fig. 2), is mainly constituted of slate and quartzite, although gneiss and marbled limestone are also present (Martínez Catalán et al. 1992, 2004). Palaeozoic fossils are poorly preserved due to the Variscan Orogeny (Gutiérrez-Marco et al. 2001), which formed $11 \mathrm{~km}$ long recumbent folds and other structures, mainly during lower Carboniferous (Martínez Catalán et al. 1992, 2004). One of these folds is the Courel recumbent fold (see Gutiérrez-Marco 2005; Fernández et al. 2007), which was declared Global Geosite (2011) and Natural Monument by the Regional Government of Galicia (2012). After the Permian-Mesozoic extension with associated diabase intrusions, some previous faults were reactivated, causing the Alpine uplifting from the Palaeocene to the Miocene (Martín-González 2009; Martín-González et al. 2012). The uplifting triggered fluvial incisions, which formed the current narrow and deep gorges and valleys in northwest Spain, as well as the development of fluvial terraces and alluvial fans from the Miocene to the Pleistocene (Heredia et al. 2015). Karst caves were developed since at least the Pleistocene (Railsback et al. 2011, 2017) and glaciers occupied the higher areas (see Pérez Alberti 2018) prior to 21 cal ka BP, where a lake recorded later the growth of Holocene forests (Santos et al. 2000; Muñoz Sobrino et al. 2001; Leira and 
Fig. 1 A Location of the Courel Mountains UGGp in the northwest of the Iberian Peninsula.

B Localities, infrastructures, deciduous forest, mixed woodlands, and vineyards. C Touristic sites, local services, and geosites
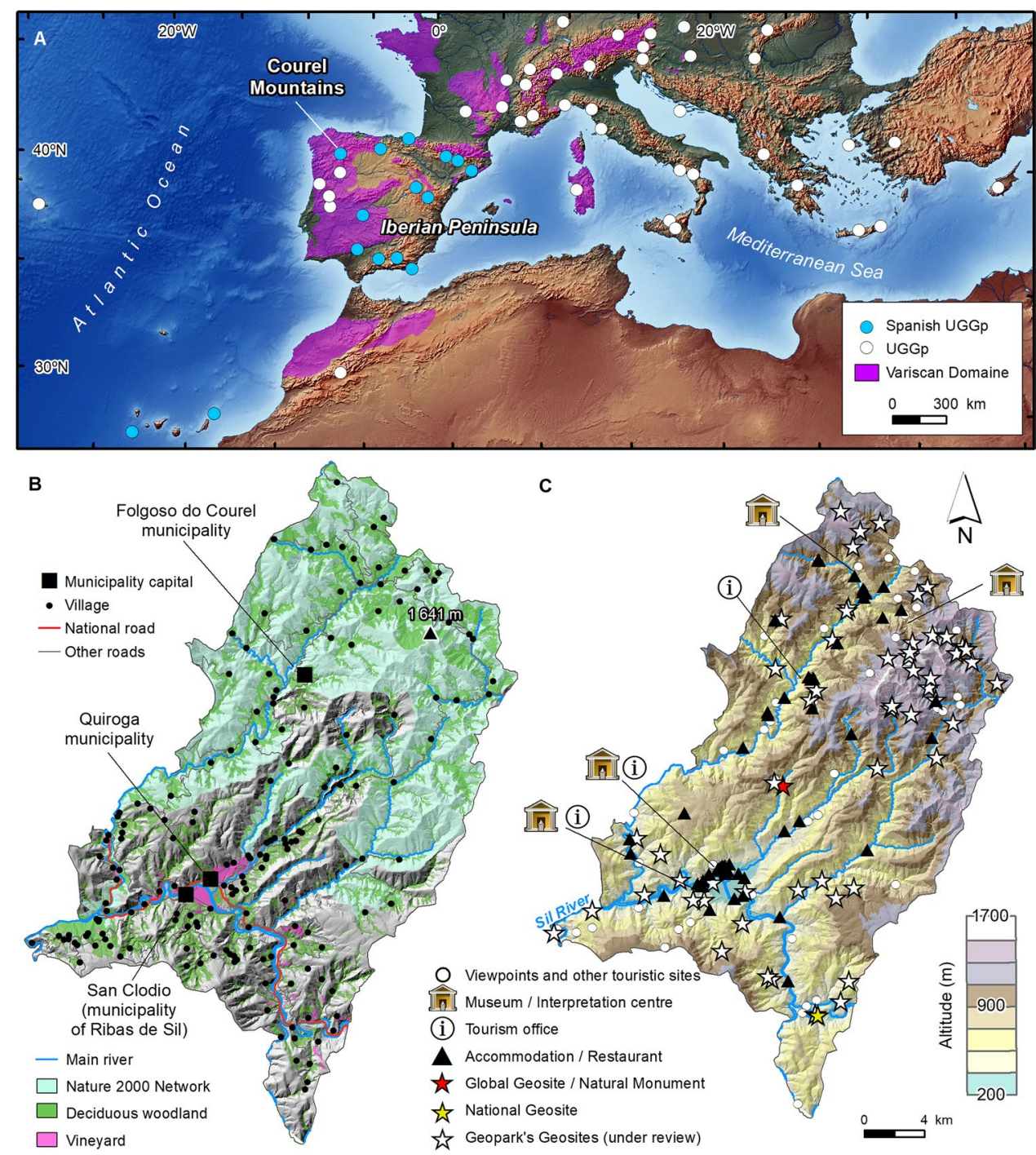

Santos 2002). Finally, periglacial and slope processes locally modelled the mountains up to the present day (Pérez Alberti 2018; Viana-Soto and Pérez-Alberti 2019). Archaeological studies largely evidenced the historical use of geological resources, including settlement areas, building stones, lime kilns, iron workshops, and $\mathrm{Au}, \mathrm{Fe}, \mathrm{Sb}$, and $\mathrm{Pb}$ mining. Palaeolithic tools and Neolithic tombs built in local stone (Lombera and Fábregas Valcarce 2011) were followed by Iron Age and Roman hillforts. The latter were fortified combining stonewalls and natural scarps to protect dwellings, also constructed in Palaeozoic rocks, using slate for roofing (Luzón Nogué and Sánchez-Palencia 1980; Álvarez Núñez 1996). The Romans mined gold deposits up to the fall of the empire (e.g. Pérez-García et al. 2000; Sánchez-Palencia et al. 2006) but hillforts continued being used after the Fall of the Roman Empire (Tejerizo-García and Canosa-Betés 2018). New villages were established on flatter areas, such as alluvial fans, large old landslides, glacial valleys, and ancient Roman open cast works. The villages have been walled and roofed using local Palaeozoic stones until this day, resulting in the current traditional villages whose noticeable architecture motivated the creation of the PVR. Castles and churches were also built with local rock material, expect for medieval abbeys, which were made of granitoids imported from nearby areas. Slate quarrying continues at present, being part of an Iberian Roofing Slate Global Heritage Stone Province (GHSP) (Cárdenes et al. 2015). These quarries constitute one of the main economic activities of the Courel Mountains UGGp, supplying roofing slate to Spain and North-Central Europe.

\section{Methodology}

The touristic route was designed in three steps: (1) definition of the route name, (2) definition of criteria for evaluating villages, and (3) selection of the villages which would constitute the PVR. 
A
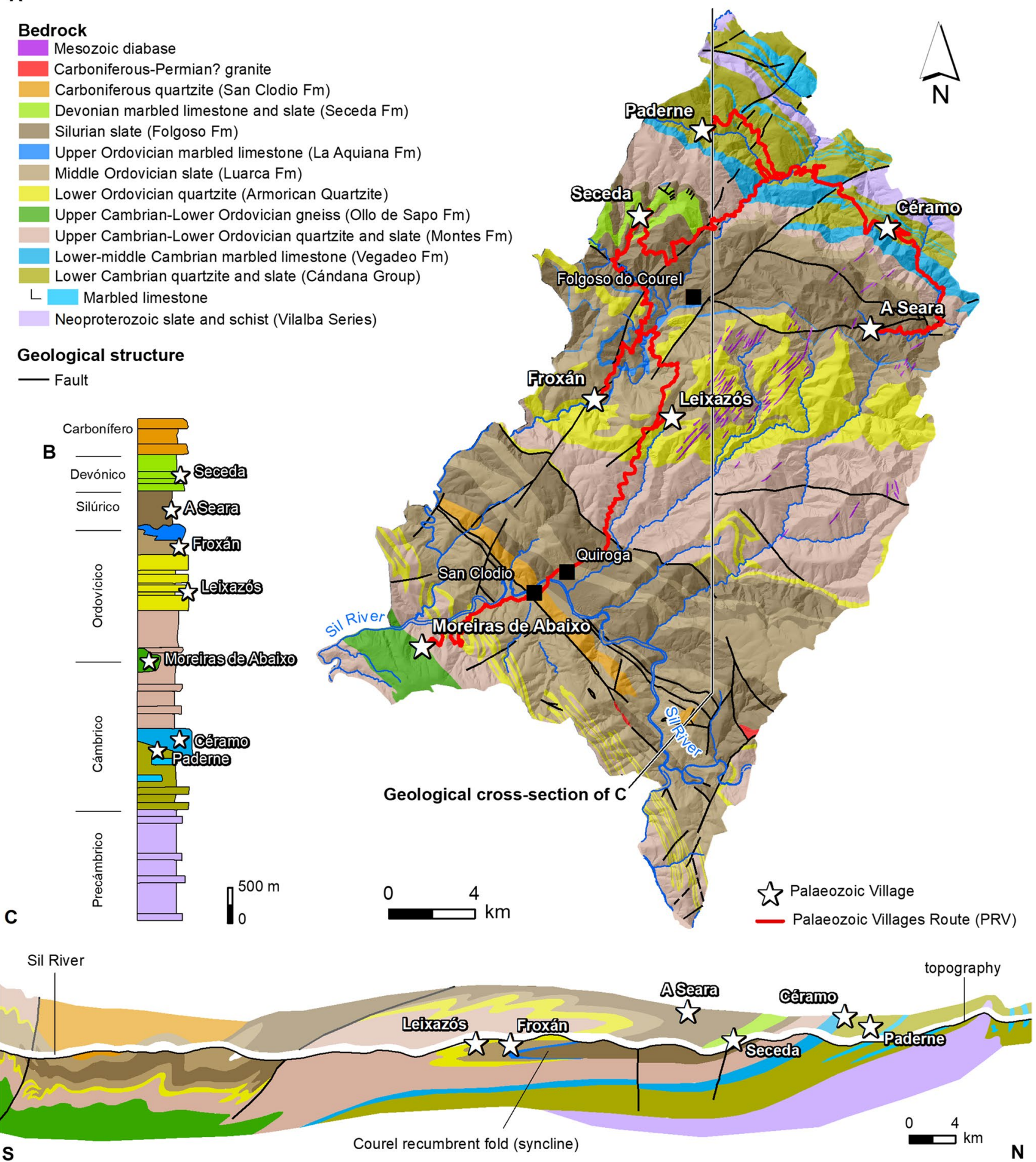

Fig. 2 A The Palaeozoic Village Route (PVR) plotted on the geological map of the Courel Mountains UGGp after Villar-Alonso et al. (2018). B Simplified stratigraphical section of the territory after Dozy (1983) and Martínez Catalán et al. (1992, 2004). C Palaeozoic Vil- lages projected on the geological cross-section after Martínez Catalán et al. (2004). Moreiras de Abaixo is not represented, as its projection falls outside of the cross-section 


\section{Route Name}

The name of the route was chosen for concisely covering the subject matter and having an attractive touristic appeal. It comes from the main Era (Palaeozoic) of the representative bedrock of the UGGp. At the same time, the System/Period (Cambrian to Devonian) of the rock used in each village is added to the village name (e.g. the Cambrian Village). This lenience of scientific rigour allowed us to break the barrier between geology and society with a name that approximately describes the geology and is also easily understandable for the larger public.

\section{Criteria for Selection of Villages}

The suitability of a village to be included in the PVR was determined by scoring five objective criteria from 0 to 3 for each of the 190 villages in the UGGp (Table 1). We based the criteria on previous works regarding tourism in rural villages (e.g. Ruhimat et al. 2018; Fang 2020). These criteria were evaluated using the geographical information system of the UGGp, which include amongst others digital elevation models, villages and infrastructures (road, railway), vegetation cover, geological and geomorphological maps, geosites, ore deposits, karst caves, cultural/archaeological sites, interesting points, viewpoints, information panels, museums and interpretation centres, and local amenities (hotels, hostels, campings, bars, restaurants) (Fig. 1B and C). The average value of these criteria constituted the score of each village.

- Representativeness of building stones with respect to the bedrock. The main lithologies of the UGGp (slate, quartzite, gneiss, and marbled limestone) and geological ages (Cambrian to Carboniferous) should be involved in the set of selected villages. Ideally, each village is associated with a specific lithology and age. In the

Table 1 Criteria used for selection of villages

\section{Score}

1. Representativeness of the Geopark's bedrock

0

1

2

3

2. Traditional architecture

0

1

2

3

3. Geoheritage

0

1

2

3

0

1

2

3

0

1

2

3

0

1

2

3
Village not mainly built in Palaeozoic stone quarried locally

Village involves mainly Palaeozoic rocks of the Geopark coming from alluvial deposits

Village built using only the most common rocks (slate and quartzite) of the Geopark

Village involving the scarce rocks (gneiss and marbled limestone) of the Geopark

Village without traditional architecture

Village with poorly preserved traditional constructions

Village with well-preserved singular constructions walled using the dry stone technique and roofed using local slate Village declared Site of Cultural Interest by the Regional Government

Village not related to any singular geological feature

Village emplaced on ancient large landslides or alluvial fans or terraces, but this is not clearly observed at the village Village emplaced on ancient large landslides or alluvial fans or terraces, being this clearly observed at the village Village is located in a Geosite or constitutes a viewpoint of a Geosite

4. Scenic beauty

Village is anthrophically degraded, showing industrial and urban area, national roads, or railways

Village located in a natural area without singular natural elements

Village with views to watercourses, native forests or remarkable mountain landscapes

Village located within a remarkable natural area with watercourses and native forests

5. Complementary activities

Suitable sites for outdoor activities or touristic sites are not present within an area of $1 \mathrm{~km}$ radius

Suitable sites for outdoor activities or tourism are present within an area of $1 \mathrm{~km}$ radius

Suitable sites for outdoor activities and tourism are present within an area of $1 \mathrm{~km}$ radius

Exhibitions are regularly organised in the village

6. Local services

Nearest accommodation and restaurants located at a distance $>10 \mathrm{~km}$

Nearest accommodation and restaurants located at a distance of 5-10 km

Nearest accommodation and restaurants located at a distance $<5 \mathrm{~km}$

Village with accommodation and restaurants 
Courel Mountains UGGp, Carboniferous rocks were not employed for settlement building; therefore, only Cambrian to Devonian rocks were considered.

- Traditional architecture. The traditional architecture of villages includes well-preserved singular buildings walled with the dry-stone walling technique and roofed using local slate from the UGGp quarries. As far as possible, modern materials as concrete, metal, or plastic should not be present or, at least, not be visible. Singular buildings include dwellings (frequently with remarkable balconies), stables, water mills, and other constructions such as structures used for the traditional curing of chestnuts. In addition, official recognitions like the declaration of "Sites of Cultural Interest by the Regional Government" increase the cultural value of a village.

- Scenic beauty. The surroundings of a village should be aesthetic and attractive, determined by the presence of natural areas including native forests, watercourses, and panoramic viewpoints (see Brilha 2016).

- Complementary activities. Complementary activities reinforce the touristic value of a village. These activities include the following: (1) exhibitions related to traditional activities or local products, (2) cultural activities, some of them related to museums and interpretation centres of the UGGp (Fig. 1C), and (3) outdoor sports (e.g. hiking, trekking, speleology, or canyoning) that would finish with a visit to a Palaeozoic Village. Only hiking routes approved by the regional federation of hiking have been considered. All these activities provide additional resources to active tourism companies, especially with unpredictable weather in the mountains.

- Local services. The presence of restaurants and accommodation in the village or nearby villages was accounted for to promote the local economy. The services of the UGGp include 38 bars and restaurants, 13 hotels, two hostels, 10 apartments in traditional houses, and one camping, accounting for approximately 700 beds (Fig. 1C).

\section{Selection of the Villages}

The number of selected villages was aimed to represent the characteristic lithologies and ages of the bedrock. In the Courel Mountains UGGp, the bedrock is mainly represented by four lithologies (slate, quartzite, gneiss, and marbled limestone) associated with four geological periods (Cambrian, Ordovician, Silurian, and Devonian) (Dozy 1983; Martínez Catalán et al. 1992, 2004; Villar Alonso et al. 2018). This representativeness was achieved by selecting the seven villages whose ratings are equal or greater than 2.00 (Fig. 3). The selected villages are Froxán (2.83 points),

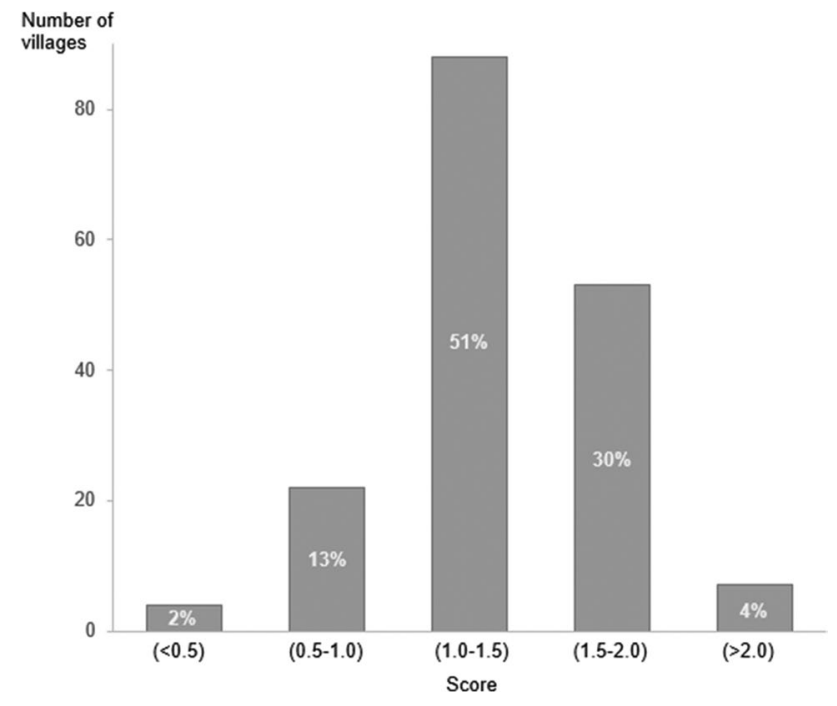

Fig. 3 Number of villages and percentage with respect to the total (190) resulted from the evaluation (scoring from 0 to 3 ) defined in the "Criteria for Selection of Villages" section and Table 1

Seceda (2.50 points), A Seara (2.50 points), Moreiras de Abaixo (2.17 points), Leixazós (2.17 points), Céramo (2.17 points), and Paderne (2.00 points), representing $4 \%$ of all the villages within the UGGp, and drawing the PVR running from the south to the north of the Courel Mountains UGGp.

\section{Results}

The PVR comprises walks to the seven selected traditional stone villages, which can be visited following a $113 \mathrm{~km}$ long route (Fig. 2). The entire route requires 2 days to complete, promoting that the visitor spends at least one night in the Courel Mountains UGGp. However, each Palaeozoic Village could be individually visited as a one-journey activity, which could be complemented with other cultural, geotouristic, and/or outdoor activities.

\section{Moreiras de Abaixo Cambrian-Ordovician Village}

Moreiras de Abaixo was constructed on the slopes of the Sil River Valley in the southwest of the Courel Mountains UGGp at $550 \mathrm{~m}$ altitude, supporting agricultural and pastoral activities and situated close to forest resources (Fig. 4A). The $400 \mathrm{~m}$ deep valley was formed by a fluvial incision coevally with the uplifting of the mountain (Martín-González 2009). In the village, around 15 traditional dwellings, barns and stables are made of angular boulders of gneiss (Fig. 4B), as well as ashlars in openings (doors, windows) and corners (Fig. 4C). Of all the Palaeozoic bedrock in the area, only gneiss rock was widely transformed into cuboid-shaped 


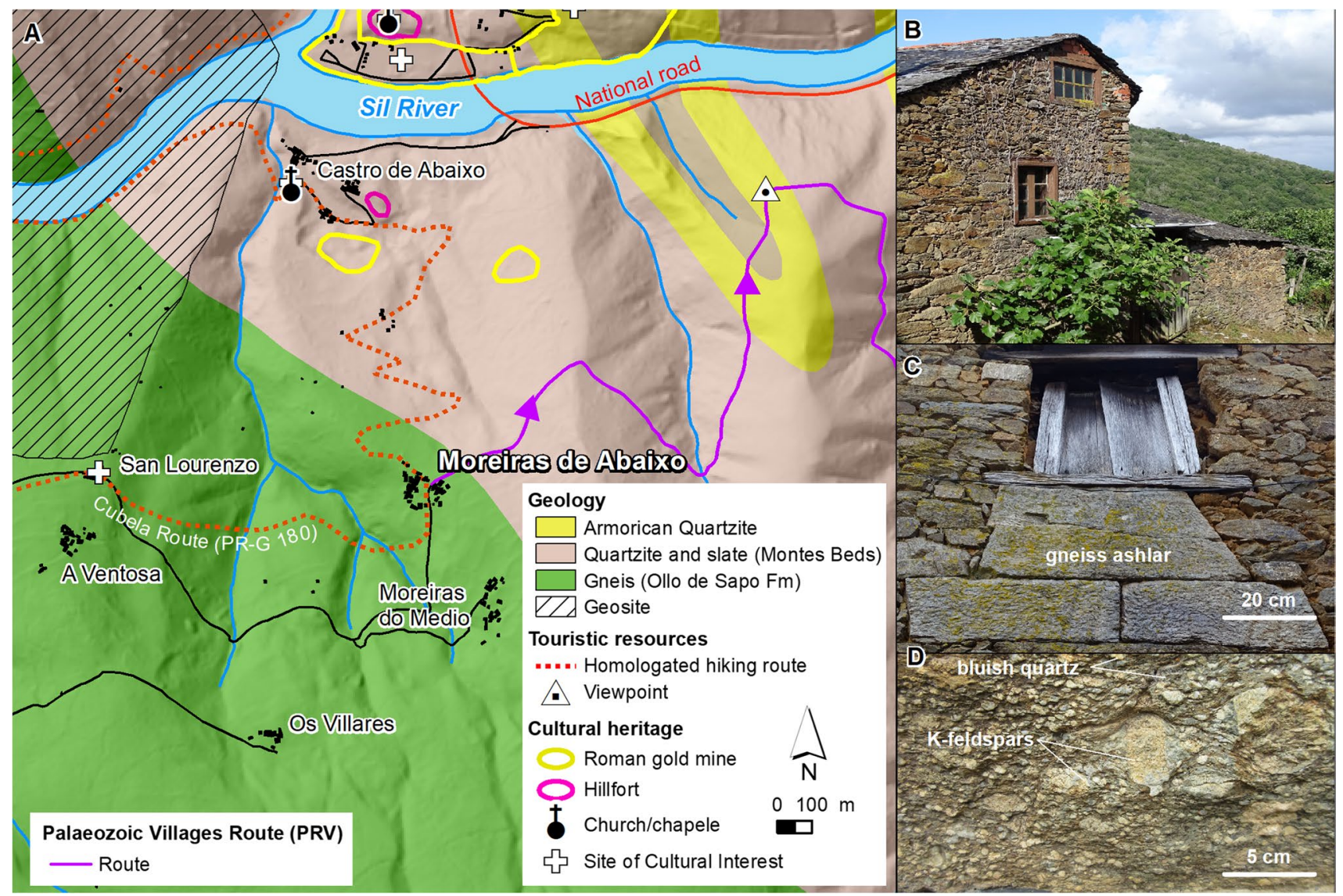

Fig. 4 Moreiras de Abaixo Cambrian-Ordovician Village. A Geological map of the surroundings after Villar-Alonso et al. (2018), and showing tourism resources and cultural heritage. B Traditional archi- tecture in gneiss. C Ashlars below a traditional window in wood. D Gneiss from Ollo de Sapo Fm. made of K-feldspar, quartz, and muscovite

of previous quartzite and schist 477-488 million years ago, making the Ollo de Sapo gneiss upper Cambrian-Lower Ordovician in age (see Fernández-Suárez et al. 2000). A visit to Moreiras de Abaixo would be complemented with a visit to the panoramic viewpoint of the River Sil Valley and nearby Roman mines. In addition, the village may also be visited within the Cubela Route (PR-G 181).

\section{Leixazós Ordovician Village}

In the geographic centre of the Courel Mountains UGGp, the village of Leixazós (707 m altitude) was built on the bottom of an incised fluvial valley (Fig. 5A-B). The village contains around 25 dwellings, stables, a watermill (Fig. 5C), and other constructions, mostly abandoned. The main building stone is Armorican Quartzite, which crops out locally and represents a singular geological in the Iberian Peninsula, Brittany, and Normandy (France) since the XIX century (e.g. Martínez Catalán et al. 1992). In the UGGp, this unit comprises $150-200 \mathrm{~m}$ of white quartzite with more than $95 \%$ of quartz content, and usually constitutes the positive reliefs crystallisation of magmas derived from the partial melting 


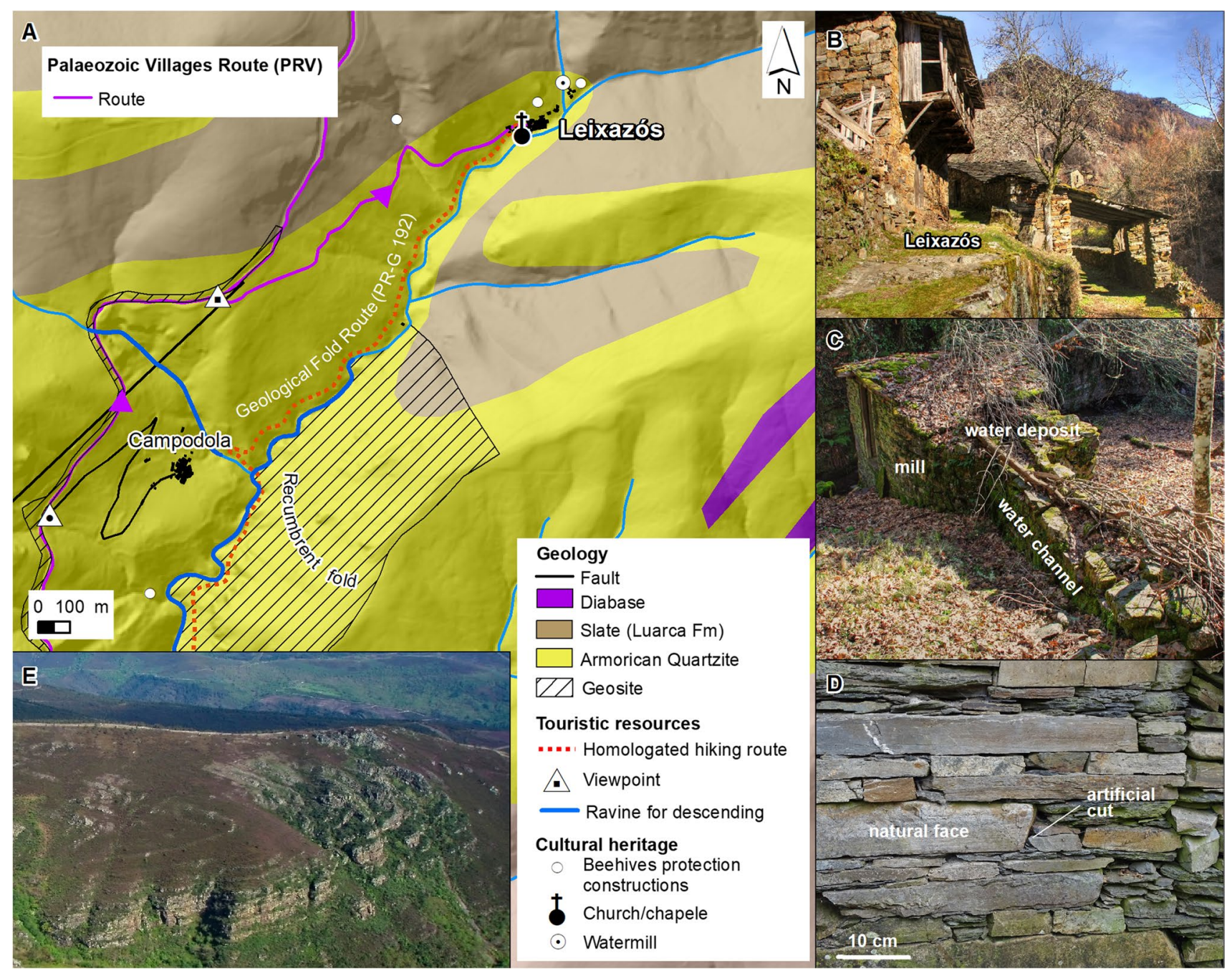

Fig. 5 Leixazós Ordovician Village. A Geological map of the area, after Villar-Alonso et al. (2018), showing the nearby tourism resources, cultural heritage, and geosites. B Traditional architecture in quartzite and wood. C Watermill built in Armorican Quartzite. D
Dry-stone in Armorican Quartzite with natural faces orientated outwards and artificial cuts hidden inside the wall. E Courel recumbent fold Natural Monument and Global Geosite seen from the viewpoints which location is shown in $\mathbf{A}$ of the Courel Mountains. The natural bedding, foliation, and fissures of the quartzite favour that the rock breaks forming sub-rectangular blocks, thereby making them adequate for dry-stone walling (Fig. 5D). In building constructions, the natural faces of quartzite blocks are usually orientated outwards, while artificial faces are hidden within the walls. This configuration reduces rock weathering by rain, freezing, and other processes.

Armorican Quartzite defines also the abundant Variscan folds, such as the Global Geosite and Natural monument of Courel recumbent syncline (Fig. 5E), observed in the surroundings of Leixazós (Martínez Catalán et al. 1992; Fernández et al. 2007). Therefore, a visit to the village allows enjoying the main geosite of the UGGp, as well as another geosite related to the Ordovician stratigraphy (Fig. 5A). In addition, a visit to the village is easily combined with outdoor activities, such as canyoning within the Armorican Quartzite, or the Campodola Geological Fold Route (PR-G 192), where Cruziana and other ichnofossils can be found within the Ordovician rocks (Fig. 5A).

\section{Froxán Ordovician Village}

Froxán is located at $450 \mathrm{~m}$ altitude on an ancient alluvial fan surrounded by native forests and woodlots, in the western-central part of the Courel Mountains UGGp (Fig. 6A). This village was declared a Site of Cultural Interest by the Regional Government in 2006 for its traditional architecture, and several stone houses have been restored recently. Froxán includes over 40 dwellings, stables, fountains, and constructions for chestnut curation, all of them walled and roofed in Ordovician slate (Fig. 6B). The penetrative foliation of the 


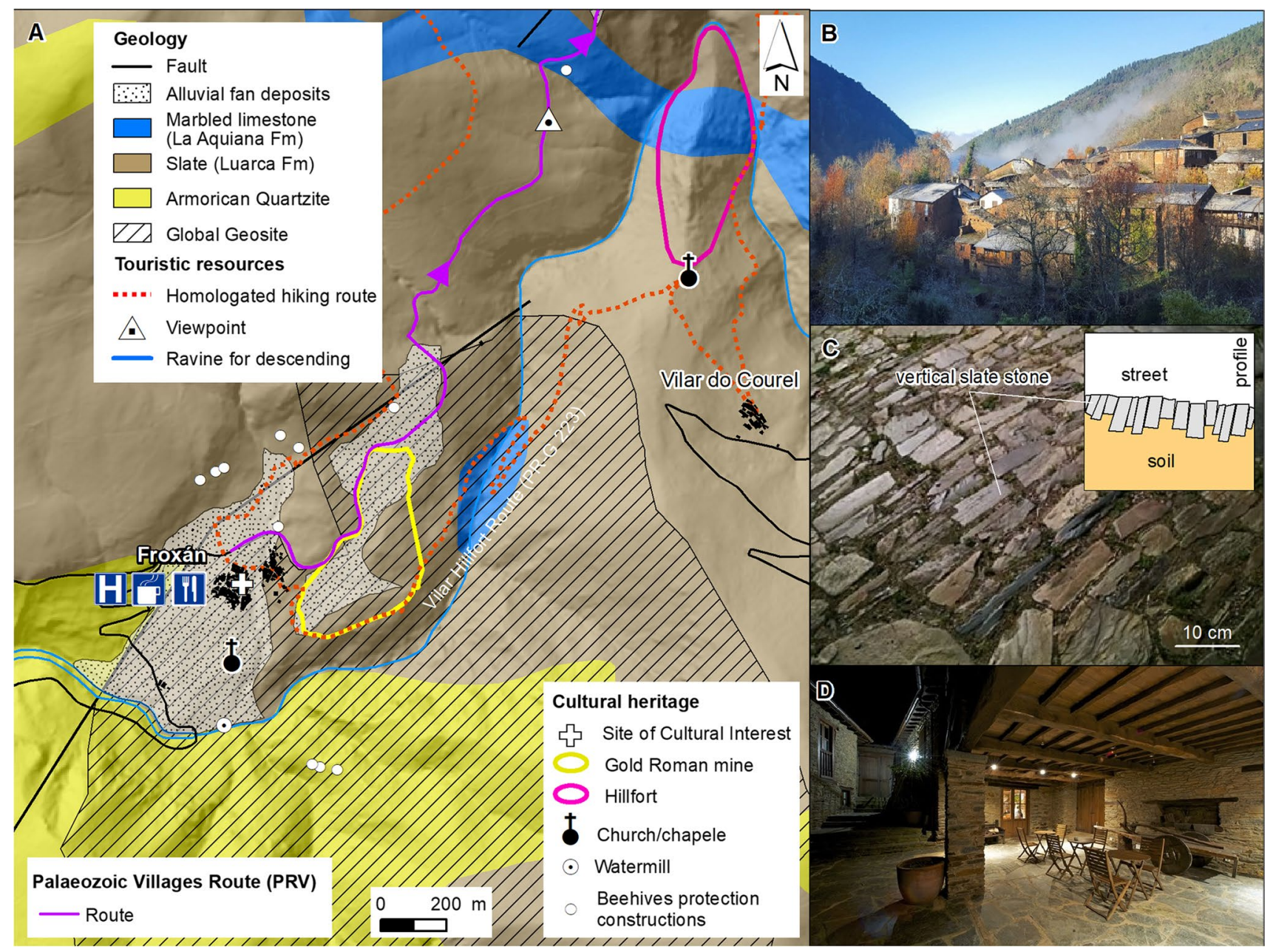

Fig. 6 Froxán Ordovician Village. A Geological map of the surroundings after Villar-Alonso et al. (2018), showing the nearby tourism resources and cultural heritage. B Overview of the village walled and roofed with Middle Ordovician slate. C Traditional technique for paving streets with vertical slate stones. D Bar-restaurant exhibiting local slate in walls, columns and floors slate facilitates its cutting in rectangular blocks for walling, or sheets for roofing. The stone streets are paved using a local technique with rectangular stones placed perpendicular to the ground for increased stability (Fig. 6C). The Ordovician slate, essentially composed of chlorite, muscovite, and quartz, was locally quarried within the Luarca Formation (Fm) (e.g. Villar Alonso et al. 2018). At present, this geological unit is extensively quarried in the UGGp forming part of the Iberian Roofing Slate GHSP (Cardenes et al. 2015).

Froxán has a restaurant-hotel walled using Middle Ordovician slate, allowing the visitor to experience dinner and accommodation within a "rocky environment" (Fig. 6D). A visit to Froxán can be combined with the Vilar Hillfort Route (PR-G 223), visits to nearby viewpoints and the ancient Roman mines that exploited gold related to alluvial fan deposits, and to ancient beehives protection constructions (Fig. 6A). These constructions are circular walls around the beehives to protect them from the brown bear (Ursus arctos), a keystone species of the Courel Mountains. Additionally, the local cultural association of the village organises exhibitions related to the curation of chestnuts and wood charcoal elaboration practices since 1999. In 2019, the chestnut exhibition received over 2000 people attendees.

\section{Seceda Devonian Village}

Seceda is situated at $760 \mathrm{~m}$ of altitude in the western-central part of the Courel Mountains UGGp, surrounded by woodlots, farmlands, and incised streams (Fig. 7A and B). The village was also declared a Site of Cultural Interest for its traditional architecture (Fig. 7B, C, and D), which include similar constructions to those in the village of Froxán (the "Froxán Ordovician Village" section). However, the streets of Seceda are narrower and partially covered by the edges of the roofs for protection against severe weather. This village also shows remarkable wood constructions which connect 
Fig. 7 Seceda Devonian Village. A Geological map of the surroundings after VillarAlonso et al. (2018), showing the nearby tourism resources, cultural heritage, and geosites. B Overview of the village walled using Devonian marbled limestone and shale. $\mathbf{C}-\mathbf{G}$ Traditional buildings and pavements. H Marbled limestone from a traditional dwelling. I Crinoids

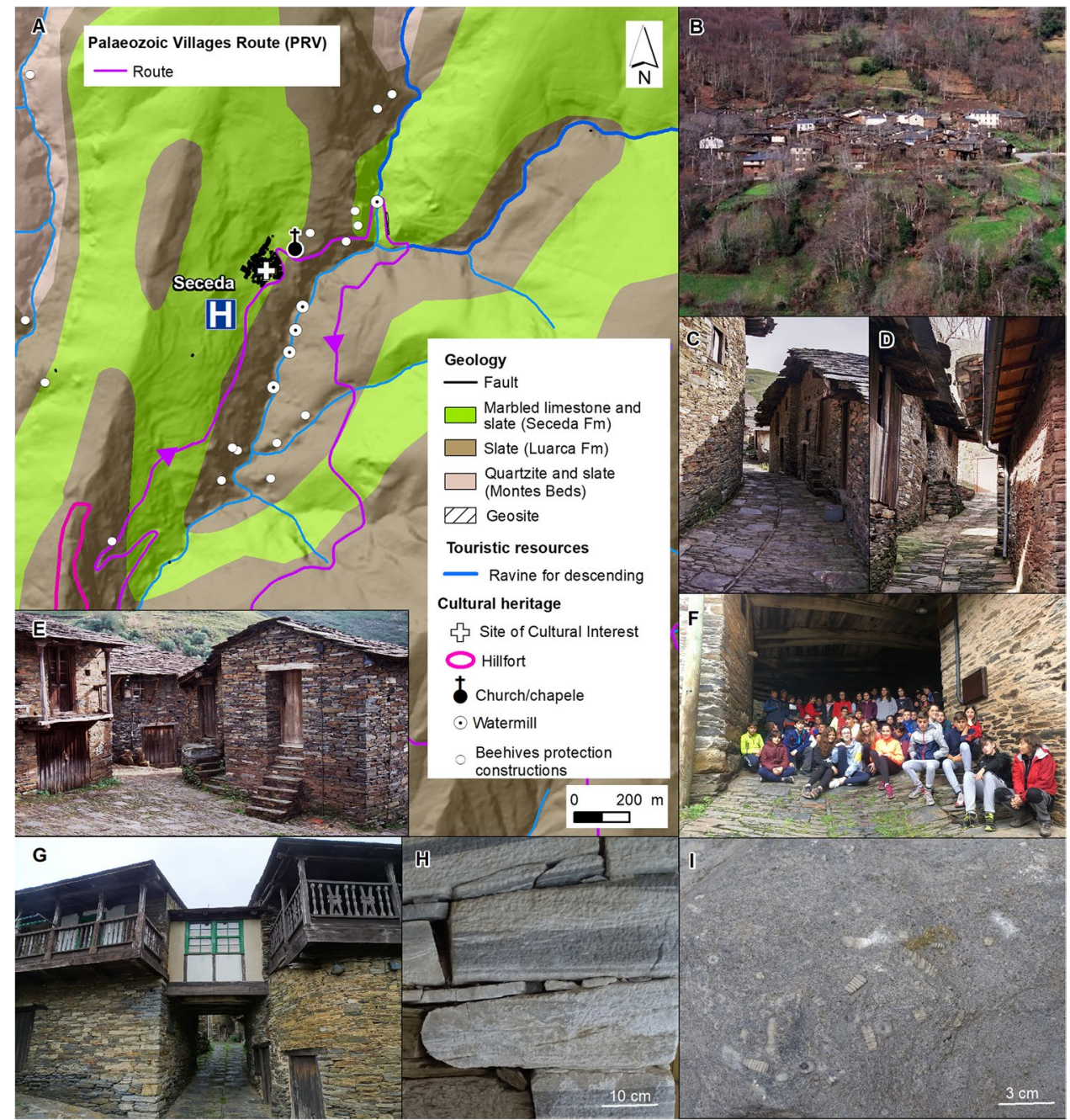

houses through bridges running over the streets (Fig. 7F). The singular stone of Seceda is Devonian marbled limestone (Fig. 7G) that crops out in the village surroundings. which are mainly populated by beech forests (Fagus sylvatica). The limestone is made of calcite with some quartz, chlorite, and muscovite and, sometimes, exhibits crinoids (Fig. 7I), as can be seen by specimen rocks displayed at the municipality tourist office. Devonian limestone is very scarce in the northwest of the Iberian Peninsula, but here constitutes the core of the Courel recumbent fold (Martínez Catalán et al. 1992). Secada is reached by a descent through ravines of partially Devonian limestone. Local accommodation is provided by two hotels located in traditional buildings. A visit could be complemented by a tour along the abundant ancient beehive constructions and the abandoned stone watermills (Fig. 7A).

\section{Paderne Cambrian Village}

Paderne is located in a valley at $873 \mathrm{~m}$ altitude surrounded by native forests and traditional chestnut woodlots (Fig. 8A and B). The village includes around 30 traditional dwellings with balconies in wood or slate with smaller constructions, and conventional bread ovens preserved in stone (Fig. 8C, D). The characteristic building stone of Paderne is Cambrian laminated grey quartzite (Fig. 8E), although the roofs are made of slate as is normally the case in traditional villages. Cambrian quartzite crops out in the surroundings of the village dipping around $30-45^{\circ}$ to the SW (Fig. 8A). This rock belongs to the Candana Group, a geological unit with a large extension in the NW of the Iberian Peninsula (e.g. Martinez Catalán et al. 1992).

The village of Paderne offers six rural apartments for tourism (Fig. 8F) summing a total of 60 beds and providing the necessary accommodation for the 2 days travelling along the PVR. Traditional locally managed chestnut forests (Castanea sativa) are a village highlight. Viewpoints around the village also allow the visitor to watch native forests and woodlands dominated by birches (Betula alba) and white oaks (Quercus pyrenaica). These forests and woodlands are connected for hikers by the Río Pequeno Route (Fig. 8A). 
Fig. 8 Paderne Cambrian Village. A Geological map of the surroundings after VillarAlonso et al. (2018), showing native forest and traditional chestnut woodlots. B Overview of Paderne and the nearby native forests. C Traditional construction. D Traditional quartzite wall with a window in wood. E Cambrian laminated grey quartzite. F Rural apartment for tourism

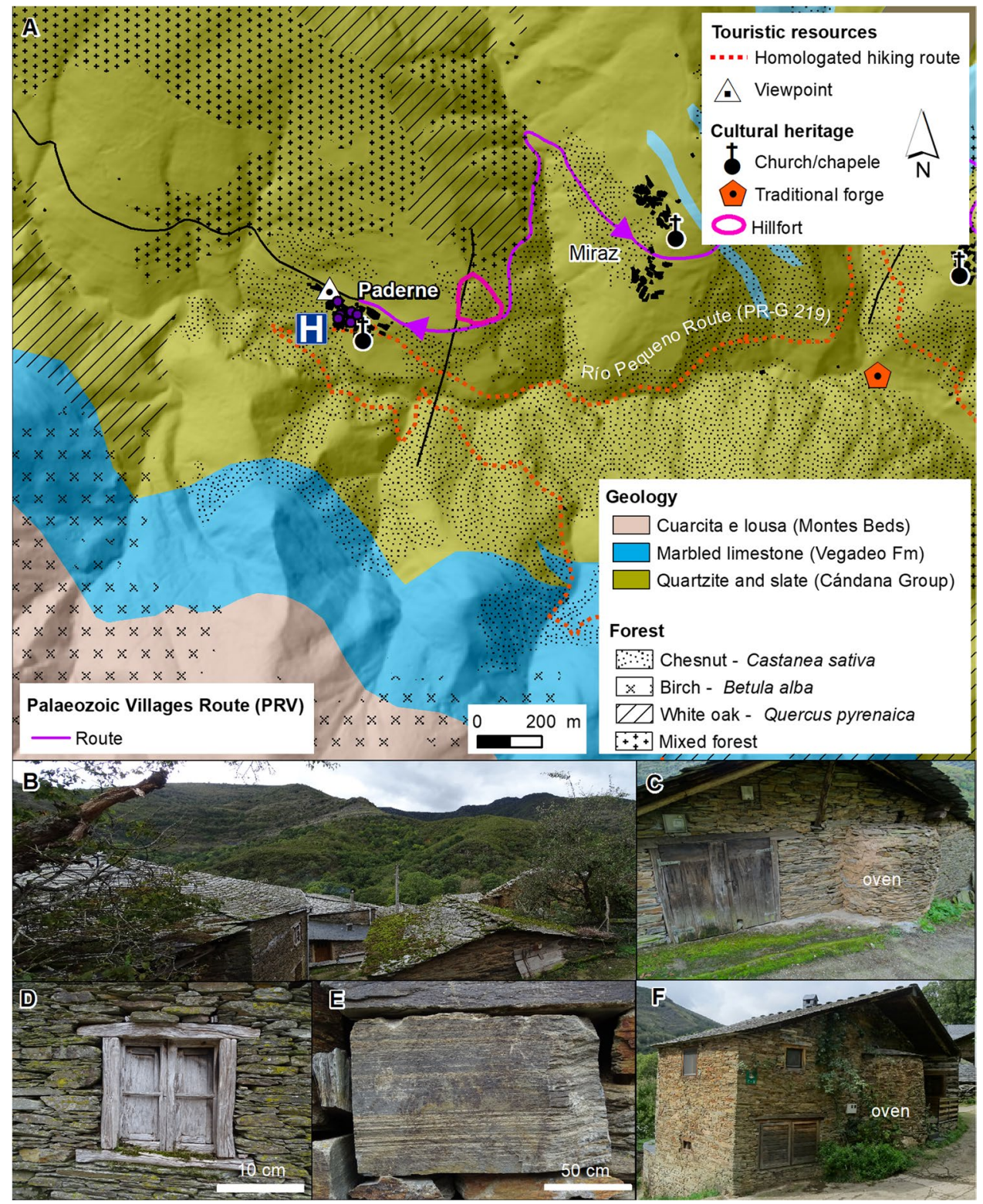

\section{Céramo Cambrian Village}

Céramo (1110 m altitude) was constructed to support iron mining activities in the northeast of the Courel Mountains UGGp (Fig. 9A), provisioning ore for the 15 documented pre-industrial workshops in the area that ran from the sixteenth to nineteenth centuries. At present day, only one resident inhabits one of the 10 dwellings in the village. The local stone used here is Cambrian marbled limestone, essentially formed by calcite and some dolomite, muscovite, chlorite, and quartz. The stratification of the calcareous rocks favours the production of cuboid blocks used for traditional walling (Fig. 9B).

Limestone was obtained from nearby calcareous areas, which can be observed from the villages and from a panoramic viewpoint (Fig. 9A and C). From this viewpoint, two glacial cirques are visible. The limestone areas host five karst caves with a total length of $5 \mathrm{~km}$. The caves are used for speleology and speleotourism conducted by local companies (Fig. 9C). Studies on stalagmites from the Arcoia cave, declared geosite, recorded climatic changes occurred in Courel Mountains during the last 550,000 years (Railsback et al. 2011, 2017). Furthermore, remains of cave and brown bears recovered from these caves and other cavities in the UGGp enabled the study of their genetics and hibernation habits during the Upper Pleistocene (see GarcíaVázquez et al. 2011; Grandal-d'Anglade et al. 2019). A visit to the Cambrian Village is complemented with visiting the microreserves (Fig. 9A) hosting endemic orchids and other native flora managed by the regional environmental group 
Fig. 9 Céramo Cambrian Village. A Geological map of the surroundings after VillarAlonso et al. (2018), showing the nearby tourism resources, cultural heritage, and geosites. B Traditional buildings walled using Cambrian marbled limestone. C Calcareous areas seen from the viewpoint, whose location is shown in A. D Speleologist enjoying a nearby cave positioned also in $\mathbf{A}$

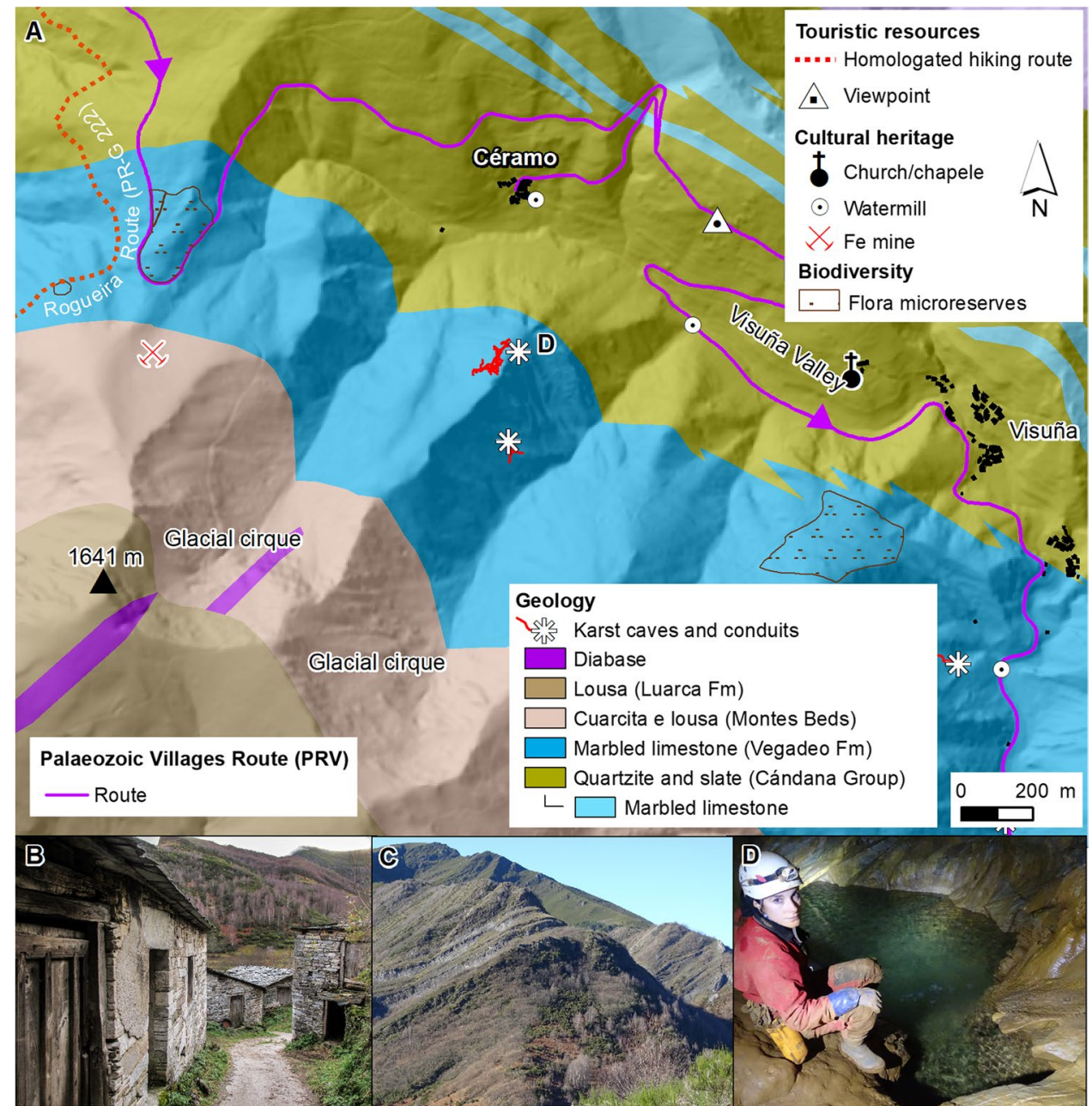

"Asociación Galega de Custodia do Territorio" and the Biodiversity Foundation of Spain.

\section{A Seara Silurian Village}

The Palaeozoic Village A Seara is situated in an ancient U-shaped glacial valley (declared geosite) at $1000 \mathrm{~m}$ altitude for pastoral and agricultural practices, and mining activities (Fig. 10A). A Seara contains over 40 dwellings, stables, and barns, as well as a bridge (Fig. 10B) and three watermills, one of them used for electricity production in the past. Traditional constructions, sometimes restored, predominantly have slate walls and roofs similar as in Froxán (the "Froxán Ordovician Village" section). In addition, slate slabs were used to close singular balconies of the houses (Fig. 10C) and to create small paved areas for agricultural applications (Fig. 10D). The Silurian slate used here is darker and sometimes silkier than the Ordovician slate of Froxán due to the occurrence of graphite (Dozy 1983). This mineral comes from the preserved organic matter accumulated in poorly oxygenated marine environments during the Silurian (e.g. Martínez Catalán et al. 1992). Mesozoic igneous rocks also occur in constructions of A Seara (Fig. 10E). These rocks mainly correspond to a diabase, identified by their concave fractures and the presence of white plagioclase. Diabase boulders are usually located at the bottom of the corners of the buildings for their protection (Fig. 10E). These boulders either come from nearby igneous dykes or were transported from the headwaters of the valley where magmatic intrusions also occur (Fig. 10A) (Villar Alonso et al. 2018). Furthermore, the diabase has long been used as a sharpening stone for knives and farming tools (Fig. 10F).

The village includes a refuge maintained by the Regional Federation of Hiking. A visit of A Seara is highlighted by a visit to two waterfalls, one traditional lime kiln, a panoramic viewpoint over the glacial valley, and a watermill located in the nearby village of Vieiros (Fig. 10A). This watermill runs for touristic exhibitions after its restoration by local residents. A Seara is connected through the trekking routes PR-G 184 and PR-G 197. 
Fig. 10 A Seara Silurian village. A Geological map of the surroundings after VillarAlonso et al. (2018), showing the nearby tourism resources, cultural heritage, and geosites. B Overview of the village walled using Devonian marble limestone. C-E Traditional buildings and pavements

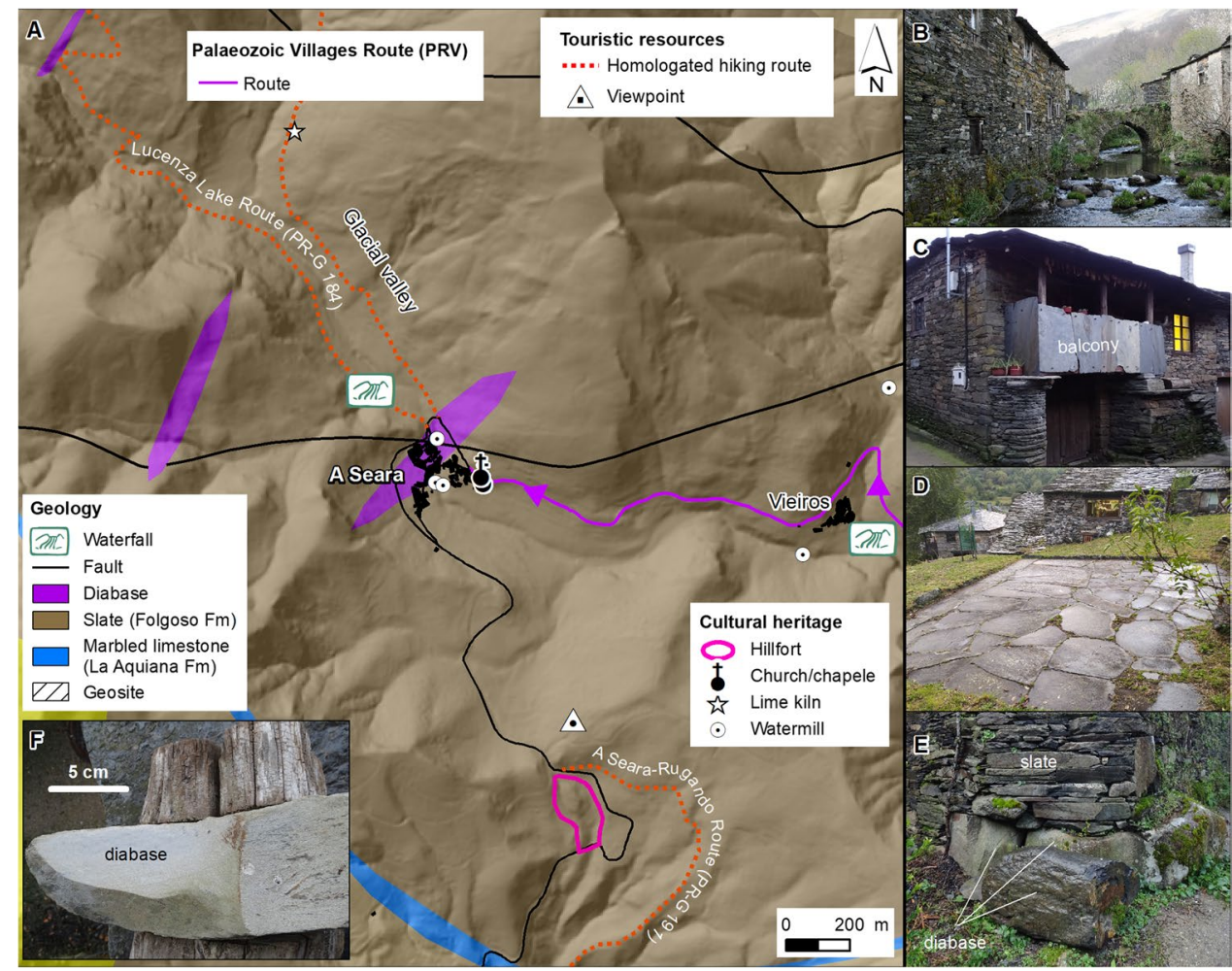

\section{Impact on the UGGp Development}

\section{New Educative Resources and Differentiating Features}

The PVR integrates the geological and cultural heritage of rural areas for geotourism activities targeted at all audiences. Visitors can familiarise themselves with the main lithologies and geological periods of the Courel Mountains UGGp by observing unweathered rocks, minerals, and fossils. The Palaeozoic Villages encourage the understanding of the role of local stones in traditional architecture, using rocks for specific functions according to its geological characteristics, e.g. quartzite and slate for walling, slate for roofing and closing balconies, quartzite metric-sized blocks for corner protection, or gneiss ashlars for openings (windows and doors). The PVR opens the opportunity to discuss the depopulation of rural areas and abandonment of local villages, raising more awareness of this problem and provide tools to UGGp to mitigate the economic and social impacts. In addition, these actions encourage close cooperation between the UGGp and the local residents. Finally, the route provides a new vision of the traditional architecture, reinforcing the relations between local geology and society as differentiating features of the Courel Mountains UGGp.

\section{Visitor Affluence}

The annual number of visitors to all the Palaeozoic Villages is currently estimated to 12,500 visitors, according to surveys carried out by the tourism offices and the Geological Museum of Quiroga. During 2018-2019, the affluence to the Palaeozoic Villages increased around 19\% (Fig. 11A). The largest growth $(+75 \%)$ took place in Leixazós Cambrian Village due to the development of activities organised by the management structure of the Courel Mountains UGGp. The increment of +3 to $+11 \%$ in Froxán, Seceda, Paderne, A Seara, and Moreiras de Abaixo villages comes from an increase in tourism, sometimes guided by local companies, and their use of local services (restaurants and accommodation). The affluence to the Céramo Cambrian Marbled limestone Village remained constant. Currently, seven local companies organise annually visits to the Palaeozoic Villages, which can also be booked through international agencies. Together, they manage around $10 \%$ of the tourist visits to the UGGp. Officials of the Courel Mountains UGGp guided only $5 \%$ of the visitors, while $10 \%$ were guided by local companies and $85 \%$ visited the Palaeozoic Villages on their own account. Indirectly, the characteristics of the PVR encourage that the visitor stays more than 1 day within the UGGp, thereby using some of the 39 restaurants, bars, hotels, hostels, camping, and apartments located in the route 
Fig. 11 A Visitors of the Palaeozoic Village Route (PVR) during 2018-2019. B Ancient traditional building in the $\mathrm{A}$ Seara Silurian Village. C Same building than $\mathbf{B}$ after restoration

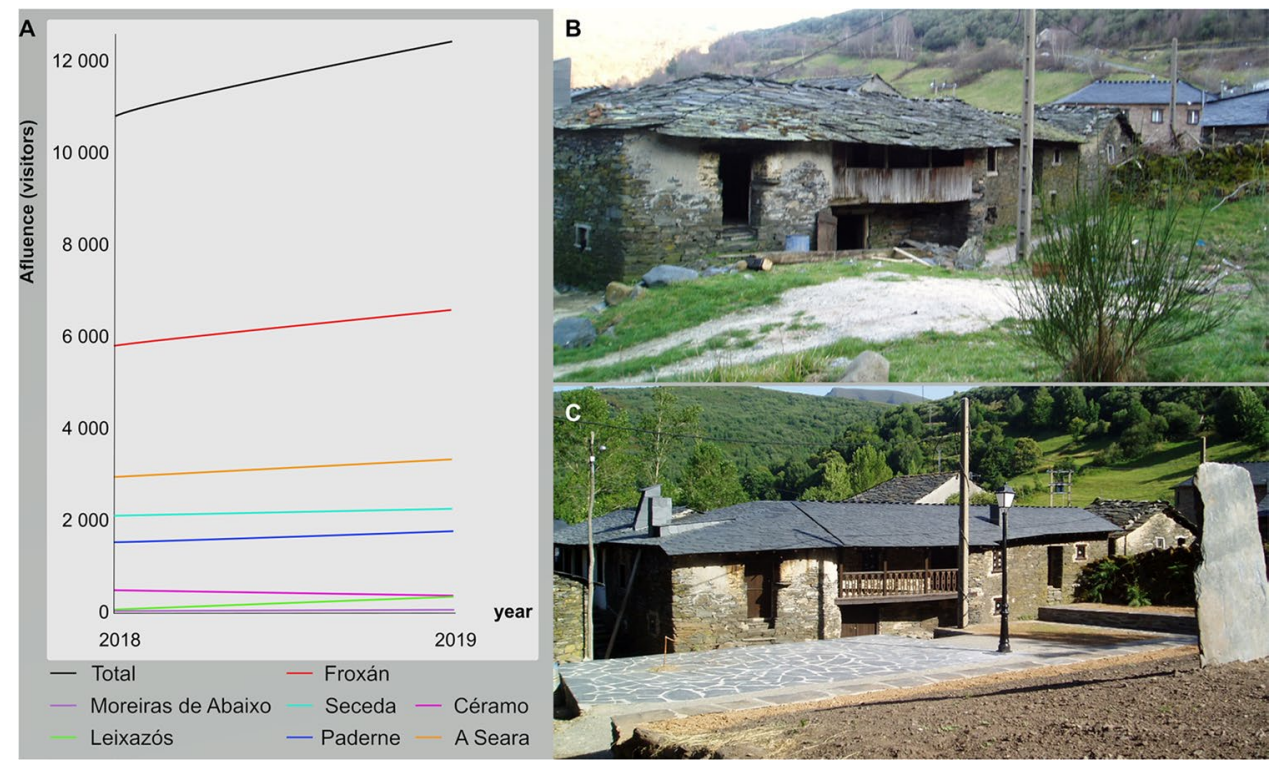

conservation is mainly carried out by the municipalities. More than 10 dwellings and other constructions have been restored since 2018 by their owners in three Palaeozoic Villages, following the traditional architecture, which obtained grants from the Regional Government owing to the management of the Ribeira Sacra-Courel Local Action Group (Fig. 11B and C). In addition, ten houses were purchased as second homes for weekends and holidays. Even though these new residents are occasional, their presence decreases the depopulation of rural villages in the UGGp.

\section{Geoconservation and Potential Problems}

The PVR does not affect the geoconservation of the Courel Mountains UGGp as the route is developed within the villages, and no additional resources required implementation to establish the route. The main potential problems could be derived from nuisances caused by tourists, such as increased traffic, full parking facilities and local services, and pollution. However, the municipalities and tourist offices have so far not reporting any significant problems related to the PVR and the coexistence of local residents. To avoid road congestions, the management structure of the Courel Mountains UGGp and tourist agents provide instructions for adequate parking and recommend a circular driving route by taking western roads moving up north and returning south following the eastern roads. Tourists usually park their cars at the entrance of the village due to the narrow streets inside. Therefore, new parking facilities are not yet required. Potential environmental impacts are minimised because the villages are located far away from the most sensitive areas of the Natura 2000 Network. 


\section{Conclusions}

The Courel Mountains UGGp established a new touristic route with educational content for a broad public to highlight the presence of Palaeozoic rock formations in the UGGp and the important role the rocks played in traditional architecture, and to avoid the depopulation of rural areas. The PVR was designed considering seven traditional villages built with local stone, selected according to five criteria: the representativeness with respect to the bedrock of the UGGp, the links to the geoheritage, the preservation of the traditional architecture, the scenic beauty, and the potential combination with other touristic outdoor activities.

The PVR constitutes a new educational resource linking lithologies, geological periods, traditional use of the geological resources, and awareness of current societal problems in rural areas. Since 2018, the route generates an increase in touristic affluence to rural villages with subsequent economic benefits, promoting the purchase and restoration of dwellings and other constructions following the local traditional architecture. These actions mitigate the degradation and depopulation of rural villages, which largely affect many geoparks and other rural areas in the Iberian Peninsula and other places in the world. The designed PVR is a fundamental example of the relationship between humans and geology, the most distinctive features of the Courel Mountains UGGp.

Acknowledgements The PVR forms part of the tourism programme of the Courel Mountains UGGp. Topographic and vegetation data displayed in the figures are from the Geographical National Institute of Spain. We acknowledge the assistance provided by Dr. Luis GonzálezMenéndez (Spanish Geological Survey). We thank also E. de Boer for proofreading the article. The PVR is possible thanks to the cooperation of local people, companies, and schools, whose promising future is a truly inspiration to the UGGp.

Author Contributions RV and MA conceived the original idea and directed the research. DB and PC designed the methdological procedure in cooperation with RV and XCB. In particular, RV reported about the specific uses of building stones and XCB provided the geological knowledge. MA carried out the funding acquisition and project administration. DB and PC wrote the original draft, with contributions by all authors to the final version.

Funding Open Access funding provided thanks to the CRUE-CSIC agreement with Springer Nature. Courel Mountains UGGp through the Ribeira Sacra-Courel Local Action Group, municipalities of Quiroga, Ribas de Sil and Folgoso do Courel, Deputy Government of Lugo Province, and the Regional Government of Galicia.

Data Availability All data and materials are public and free to use.

\section{Declarations}

Conflict of Interest The authors declare no competing interests.
Open Access This article is licensed under a Creative Commons Attribution 4.0 International License, which permits use, sharing, adaptation, distribution and reproduction in any medium or format, as long as you give appropriate credit to the original author(s) and the source, provide a link to the Creative Commons licence, and indicate if changes were made. The images or other third party material in this article are included in the article's Creative Commons licence, unless indicated otherwise in a credit line to the material. If material is not included in the article's Creative Commons licence and your intended use is not permitted by statutory regulation or exceeds the permitted use, you will need to obtain permission directly from the copyright holder. To view a copy of this licence, visit http://creativecommons.org/licenses/by/4.0/.

\section{References}

Alcalá L (2018) Dinópolis, halfway between amusement park and science museum: how to develop geotourism in a region undergoing depopulation. Int J Geoheritage Park 6:40-71. https://doi. org/10.17149/ijgp.j.issn.2577.4441.2018.02.004

Álvarez RF 2020 Geoparks and education: UNESCO global geopark Villuercas-Ibores-Jara as a case study in Spain. Geosci 10 https://doi.org/10.3390/geosciences 10010027

Álvarez Núñez A (1996) Castro da Torre (Sobredo, O Courel). Informe de la intervención arqueológica de 1993. Boletín La Real Soc Geográfica 7:9-32

Brilha J (2018) Geoheritage and geoparks Geoheritage Assessment, Prot Manag 323-335 https://doi.org/10.1016/B978-012-809531-7.00018-6

Brilha J (2016) Inventory and quantitative assessment of geosites and geodiversity sites: a review. Geoheritage 8:119-134. https://doi. org/10.1007/s12371-014-0139-3

Cardenes V, Cnudde V, Cnudde JP (2015) Iberian roofing slate as a Global Heritage Stone Province resource. Episodes 38:97-105. https://doi.org/10.18814/epiiugs/2015/v38i2/005

Carvalho IS, Henriques MH, Castro ARSF, Félix YR (2020) Promotion of the Geological Heritage of Araripe Unesco Global Geopark, Brazil: the Casa da Pedra Reference Center Geoheritage 12 https://doi.org/10.1007/s12371-020-00452-9

Cunha S, Silva A, Flores Herráez C, et al (2011) Atlas Climático Ibérico-Iberian Climate Atlas. Agencia Estatal de Meteorología, Instituto de Meteorologia de Portugal, Madrid

de Lombera HA, Fábregas Valcarce R (2011) To the West of Spanish Cantabria: the Palaeolithic settlement of Galicia. Bristish Archaeol Reports (BAR) 2283:2283

De Uña-Álvarez E, Villarino-Pérez M (2017) Adaptive strategies for inland touristic destinations (Sil Canyon, Galicia, Nw Spain). Cuad Tur 40:203-224. https://doi.org/10.6018/turismo.40. 309671

Dozy JJ (1983) The geology of the region to the Southeast of Lugo (N.W. Spain). Leidse Geol Meded 52:513-524

Fang W-T (2020) Tourism in emerging economies. Springer, Singapore

Fernández-Suárez J, Dunning GR, Jenner GA, Gutiérrez-Alonso G (2000) Variscan collisional magmatism and deformation in NW Iberia: constraints from U-Pb geochronology of granitoids. J Geol Soc London 157:565-576. https://doi.org/10.1144/jgs.157.3.565

Fernández FJ, Aller J, Bastida F (2007) Kinematics of a kilometric recumbent fold: The Courel syncline (Iberian massif, NW Spain). J Struct Geol 29:1650-1664. https://doi.org/10.1016/j. jsg.2007.05.009

Gao J, Wu B (2017) Revitalizing traditional villages through rural tourism: a case study of Yuanjia Village, Shaanxi Province, China. Tour Manag 63:223-233. https://doi.org/10.1016/j.tourm an.2017.04.003 
García-Vázquez A, Grandal-d'Anglade A, Rodríguez MV, Romaní JRV (2011) On the relation between cave and brown bears in $\mathrm{O}$ Courel Sierra (Galicia, NW Spain). Quat Hors-Série 4:59-69

Gordon JE (2018) Geoheritage, geotourism and the cultural landscape: enhancing the visitor experience and promoting geoconservation Geosci 8 https://doi.org/10.3390/geosciences8040136

Grandal-d'Anglade A, Pérez-Rama M, García-Vázquez A, GonzálezFortes GM (2019) The cave bear's hibernation: reconstructing the physiology and behaviour of an extinct animal. Hist Biol 31:429-441. https://doi.org/10.1080/08912963.2018.1468441

Guitián J, Guitián P, Magrach A et al (2012) Effect of management and spatial characteristics on plant species richness of Castanea sativa Mill. woodlots in the NW Iberian Peninsula. J for Res 17:98-104. https://doi.org/10.1007/s10310-011-0261-x

Gutiérrez-Marco JC, Sarmiento GN, Robardet M et al (2001) Upper Silurian fossils of bohemian type from NW Spain and their palaeogeographical significance. J Czech Geol Soc 46:247-258

Gutiérrez-Marco JC (2005) El primer mirador geológico de Galicia (Gran pliegue acostado de O Courel, Lugo). De Re Metallica 5:13-20

Heredia N, Fernández LP, Martín-González F, Bahamonde JR (2015) Depositional style and tectonostratigraphic evolution of El Bierzo tertiary sub-basin (Pyrenean orogen, NW Spain). Geol Acta 13:1-23. https://doi.org/10.1344/GeologicaActa20 15.13.1.1

Hernández Sampelayo P (1922) Hierros de Galicia. Memorias Del Instituto Geológico España 1:1-483

Hilario A, Carcavilla L (2020) Twenty years of Spanish geoparks: analysis and future prospects. Geoheritage 12:87. https://doi. org/10.1007/s 12371-020-00510-2

La Felice S, Abebe T, Aquino A et al (2019) Geological and cultural heritage: dissemination experiences in Tuscany. Heritage 2:2171-2182. https://doi.org/10.3390/heritage2030131

Lane B, Kastenholz E (2015) Rural tourism: the evolution of practice and research approaches - towards a new generation concept? J Sustain Tour 23:1133-1156. https://doi.org/10.1080/09669582. 2015.1083997

Larsen PB, Wijesuriya G (2015) Nature-culture interlinkages in World Heritage Bridging the gap. World Herit 75:4-15

Leira M, Santos L (2002) An early Holocene short climatic event in the northwest Iberian Peninsula inferred from pollen and diatoms. Quat Int 94:3-12

Luzón Nogué JM, Sánchez-Palencia FJ (1980) El Caurel. Excavaciones arqueológicas en España ${ }^{\circ} 110$. Ministerio de Cultura, Madrid

Mallafrè Balsells C, Costa Jover A, Coll Pla S, et al (2019) DryStone Walls as Touristic Attractive. Comparative Between Northeast and Southwest of Iberian Peninsula. In: Monteiro J, Silva AJ, Mortal A, et al. (eds) NCREaSE 2019. Springer, Cham

Martín-González F (2009) Cenozoic tectonic activity in a Variscan basement: evidence from geomorphological markers and structural mapping (NW Iberian Massif). Geomorphology 107:210 225. https://doi.org/10.1016/j.geomorph.2008.12.008

Martín-González F, Barbero L, Capote R et al (2012) Interaction of two successive Alpine deformation fronts: cnstraints from lowtemperature thermochronology and structural mapping (NW Iberian Peninsula). Int J Earth Sci 101:1331-1342. https://doi. org/10.1007/s00531-011-0712-9

Martínez Catalán JR, Fernández-Suárez J, Jenner GA et al (2004) Provenance constraints from detrital zircon $\mathrm{U}-\mathrm{Pb}$ ages in the NW Iberian Massif: implications for Palaeozoic plate configuration and Variscan evolution. J Geol Soc London 161:463-476. https://doi.org/10.1144/0016-764903-054

Martínez Catalán JR, Hacar Rodríguez MP, Villar Alonso P et al (1992) Lower Paleozoic extensional tectonics in the limit between the West Asturian-Leonese and Central Iberian Zones of the Variscan Fold-Belt in NW Spain. Geol Rundschau 81:545-560. https://doi.org/10.1007/BF01828614

Montero P, Talavera C, Bea F (2017) Geochemical, isotopic, and zircon (U-Pb, O, Hf isotopes) evidence for the magmatic sources of the volcano-plutonic Ollo de Sapo Formation, Central Iberia. Geol Acta 15:245-260. https://doi.org/10.1344/GeologicaA cta2017.15.4.1

Muñoz Sobrino C, Ramil-Rego P, Rodríguez Guitián MA (2001) Vegetation in the mountains of northwest Iberia during the last glacial-interglacial transition. Veg Hist Archaeobot 10:7-21. https://doi.org/10.1007/PL00013366

Nowlan GS, Bobrowsky P, Clague J (2004) Protection of geological heritage: a North American perspective on Geoparks. Episodes 27:172-176. https://doi.org/10.18814/epiiugs/2004/v27i3/003

Pereira D, Marker B (2016) The value of original natural stone in the context of architectural heritage. Geosci 6:1-9. https://doi. org/10.3390/geosciences6010013

Pérez-García LC, Sánchez-Palencia FJ, Torres-Ruiz J (2000) Tertiary and Quaternary alluvial gold deposits of northwest Spain and Roman mining (NW of Duero and Bierzo Basins). J Geochemical Explor 71:225-240. https://doi.org/10.1016/S0375-6742(00) 00154-0

Pérez Alberti A (2018) Polígonos Rev Geogr 28:183-209. https:// doi.org/10.18002/pol.v0i28.4293

Railsback LB, Liang F, Vidal Romaní JR et al (2011) Petrographic and isotopic evidence for Holocene long-term climate change and shorter-term environmental shifts from a stalagmite from the Serra do Courel of northwestern Spain, and implications for climatic history across Europe and the Mediterranean. Palaeogeogr Palaeoclimatol Palaeoecol 305:172-184. https://doi.org/ 10.1016/j.palaeo.2011.02.030

Railsback LB, Liang F, Vidal Romaní JR et al (2017) Radiometric, isotopic, and petrographic evidence of changing interglacials over the past 550,000 years from six stalagmites from the Serra do Courel in the Cordillera Cantábrica of northwestern Spain. Palaeogeogr Palaeoclimatol Palaeoecol 466:137-152. https:// doi.org/10.1016/j.palaeo.2016.11.020

Ramsay T (2017) Fforest Fawr Geopark-a UNESCO Global Geopark distinguished by its geological, industrial and cultural heritage. Proc Geol Assoc 128:500-509. https://doi.org/10.1016/j. pgeola.2016.12.010

Ruhimat M, Eridiana W, Setianata AA (2018) Eligibility of traditional village as the object of educational tourism IOP Conf Ser Earth Environ Sci 145 https://doi.org/10.1088/1755-1315/ $145 / 1 / 012073$

Sá AA, Rocha D (2020) Arouca UNESCO Global Geopark: geomorphological diversity fosters local development. In: Vieira G, Zêzere J, Mora C (eds) Landscapes and Landforms of Portugal. Springer, Cham, pp 329-340

Sánchez-Mesa L (2019) Planning territorial policies against inner areas depopulation in Spain: keys for sustainable management of cultural and environmental resources. Capitale Cult 19:53-81

Sánchez-Palencia FJ, Fernández-Posse MD, Saco O, del Valle A et al (2006) Roman gold mines of the northwestern Hispania. In: Morillo Cerdán A, Aurrecoechea-Fernández J (eds) Roman Army in Hispania: An Archaeological Guide. Universidad de León, León, pp 127-150

Santos L, Vidal Romaní JR, Jalut G (2000) History of vegetation during the Holocene in the Courel and Queixa Sierras, Galicia, northwest Iberian Peninsula. J Quat Sci 15:621-632. https://doi. org/10.1002/1099-1417(200009)15:6\%3c621::AID-JQS524\% 3e3.0.CO;2-L

Scarlett JP, Riede F (2019) The dark geocultural heritage of volcanoes: combining cultural and geoheritage perspectives for mutual benefit. Geoheritage 11:1705-1721. https://doi.org/10. 1007/s12371-019-00381-2 
Takenouchi K, Torigoe H, Brown T (2018) Geotourism in Itoigawa UNESCO Global Geopark, Japan. In: Handbook of Geotourism. Edward Elgar Publishing, Cheltenham, UK

Tejerizo-García C, Canosa-Betés J (2018) Power, control and social agency in post-roman northern Iberia: an archaeological analysis of hillfort occupations. J Mediev Iber Stud 10:295-323. https://doi.org/10.1080/17546559.2018.1504383

Telbisz T, Gruber P, Mari L et al (2020) Geological heritage, geotourism and local development in Aggtelek National Park (NE Hungary) Geoheritage 12 https://doi.org/10.1007/ s12371-020-00438-7

Van Geert F (2019) The uses and challenges of the geopark label as a place branding tool. The case of the Geopark of the Tremp
Basin-Montsec (Catalonia-Spain). Int J Geoheritage Park 7:7284. https://doi.org/10.1016/j.ijgeop.2019.03.005

Viana-Soto A, Pérez-Alberti A (2019) Periglacial deposits as indicators of paleotemperatures. A case study in the Iberian Peninsula: the mountains of Galicia. Permafr Periglac Process 30:374-388. https://doi.org/10.1002/ppp.2026

Villar Alonso P, Portero Urroz G, González Cuadra P, et al (2018) Mapa Geológico Digital continuo E. 1:50.000, Zona Centroibérica. Dominio Ollo de Sapo. In: Geológico Digit. Contin. España [en línea]. Inst. Geológico y Min. España. 